\title{
Case Study of the Strategy in Concissing Essays of Excellent Student
}

Rozaiman bin Makmun, Roslina binti Abu Bakar, Sri Kartika binti Hj Abdul Rahman, Noradinah binti Hj Jaidi

To Link this Article: http://dx.doi.org/10.6007/IJARBSS/v11-i4/9662

DOI:10.6007/IJARBSS/v11-i4/9662

Received: 08 February 2021, Revised: 16 March 2021, Accepted: 24 March 2021

Published Online: 22 April 2021

In-Text Citation: (Makmun et al., 2021)

To Cite this Article: Makmun, R. bin, Bakar, R. binti A., Rahman, S. K. binti H. A., \& Jaidi, N. binti H. (2021). Case Study of the Strategy in Concissing Essays of Excellent Student. International Journal of Academic Research in Business and Social Sciences, 11(4), 1098-1115.

Copyright: (c) 2021 The Author(s)

Published by Human Resource Management Academic Research Society (www.hrmars.com)

This article is published under the Creative Commons Attribution (CC BY 4.0) license. Anyone may reproduce, distribute, translate and create derivative works of this article (for both commercial and non-commercial purposes), subject to full attribution to the original publication and authors. The full terms of this license may be seen at: http://creativecommons.org/licences/by/4.0/legalcode

Vol. 11, No. 4, 2021, Pg. 1098 - 1115

Full Terms \& Conditions of access and use can be found at http://hrmars.com/index.php/pages/detail/publication-ethics 


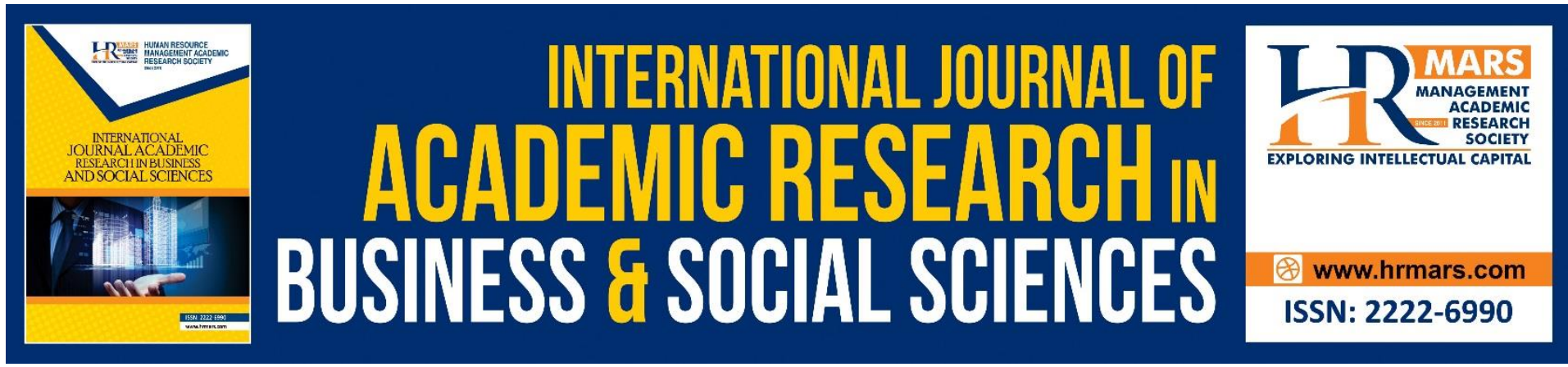

\title{
Case Study of the Strategy in Concissing Essays of Excellent Student
}

\author{
Rozaiman bin Makmun, PhD
}

Malay Language and Literacy Academic Group, Sultan Hassanal Bolkiah Institute of Education, Universiti Brunei Darussalam, Gadong, BE1410, Brunei Darussalam

Email: rozaiman.makmun@ubd.edu.bn

\author{
Roslina binti Abu Bakar, PhD \\ Malay Language Department, Faculty of Modern Language and Communication, Universiti \\ Putra Malaysia, Serdang, 43400 Selangor, Malaysia \\ Email: lynabubakar@upm.edu.my
}

\begin{abstract}
Sri Kartika binti Hj Abdul Rahman, MEd
Malay Language and Literacy Academic Group Sultan Hassanal Bolkiah Institute of Education Universiti Brunei Darussalam, Gadong, BE1410, Brunei Darussalam

Email: kartika.rahman@ubd.edu.bn
\end{abstract}

Noradinah binti Hj Jaidi, MEd

Malay Language and Literacy Academic Group, Sultan Hassanal Bolkiah Institute of Education, Universiti Brunei Darussalam, Gadong, BE1410, Brunei Darussalam

Email: noradinah.jaidi@ubd.edu.bn

\begin{abstract}
This study summarizes the strategy of excellent students in the process of abridging essays in classrooms. The description of the form of action in the process of abridging essay by excellent students can be used as a guideline to increase the skills of abridging essays among the secondary school students. This study is intended to investigate the steps of abridging essays that becomes the practice of excellent students. Rozaiman (2009) states that the weakness of students at school (year 7 to 11) and pre-university in the component of abridging essays is prevalent and still becomes a grieveances of teachers until now. Therefore, this study is done to achieve several objectives that is to highlight the skills of students interacting with material or text that is given by teachers and analyze student perception in the process of abridging essays. To achieve the study objective, this study applies the qualitative method. The outcomes of this study can depict the practice of excellent students in abridging essays through three stages as effective guidance steps in teaching of abridging essays. In every level also is displayed various ways of overcoming weakness of student in the skill of abridging paragraphs.
\end{abstract}

Keywords: Case Study, Strategy, Abridging Essays, Excellent Student 


\section{Introduction}

In the Malay Language subject, there is a learning component of abridging essays. In the ethics of teaching and learning, students are presented with writing material in the form of text or essays. With the guidance of teachers, study will interact with the text, read, understand, think critically, identify information and use ideas or information to produce abridged texts according to the limit of words that is set by the teacher or question. The item that is important in this component is the skill to reiterate facts concisely using words of their own. In other words, student is trained not to copy the facts exactly as written by the original writer. This shows that the skill of abridging essays is needed to be mastered by students and not only to master other specific skills in language, this is also needed by students in gaining knowledge in its totality. Learning essay abridging is a lifetime education. This is because skills that are involved in abridging essays are also useful in the everyday life, let alone in the workplace:

Next, in the workplace, the secretary, reporter, news caster and its kind needs the same skills to abridge the contents in talks, lectures, or meetings, and its kind (Abd, 2000). University students are also often given the task to produce abridges towards readings materials by making synthesis of several readings sources. In the thesis has also has a section of literature review that need the skills of analysis, abridging, summarizing and synthesis. As a matter of fact, there is now a branch of academic writing or research that is called as the systematic literature analysis or review that also benefits the skills of abridging and summarizing reading materials.

\section{Background of Study}

In the age of globalization, information is something that is valuable. Every aspect or field of life needs information to make us understand and advance it. With the existance of electronic media that are sophisticated such as the internet and Industrial Revolution 4.0, information spreads to whole of the world in a split second. This means that communication is a need that is needed to happen in our everyday lives.

However, without the skills of gathering information, understanding information and applying information, we cannot move anywhere, we cannot advance ourserlves let alone to advance the nation, country and religion. Therefore, the skill of interacting with information is of the upmost important and has to be mastered since school times. In the globalization era, now information spreads to anywhere through oral communication and writing. Communication mediums now exist in various forms from books to electronic such as the internet, fax and its kind. The skill of communication and sharing of information must be mastered by students since school times so that the process of communication can be practiced smoothly and effectively. The statement is as the following opinion:

Communicating is a need for every individual that happens everyday. This is because we are always coummunicating with others. The connection is purposed to either to express our opinions or feelings. The connection between us and others goes through communication processes. With that we can say communication is a process of an individual sharing or exchange of ideas, information and feelings with others. When communication process happens well, it will ease the delivery and receiving of information. In contrast if the communication processs did not happen well, wrong interpretation or misunderstanding occuring between the individuals becomes a possibility (Abdul, Nuraini \& Mohd, 2003:16). 


\section{Problem Statement}

Abridging essays are not only abridging text based on the number of words that is determined by the question. Abridging essays needs students to understand texts and identify important contents while rewriting the contents with their own words based on the number of that is determined. The skills of abridging essays is a practice for students to master the skill of gathering and describing information.

Unfortunately, these skills are less mastered by students. Consequently, students have the tendency to solve their tasks with abridging the number of words only. If this continues to happen, a society that is not aware of information, not skillful in using information, and is not able to apply information will be born. Therefore, the society will not be able to interact with information that is around us, let alone information across the world through the internet.

According to Rozaiman (2009) the weakness of students in schools (of year 7 to 11) and preuniversity in the component of abridging essays is prevalent and still is the grievence of the schools until now. This is further strengthened by the need of the professional development program that is organized by the Institute of Sultan Hassanal Bolkiah education as requested by the Curriculum Development Department to give a short course on the teaching of abridging essays for Malay Language teachers in the year of 2015. One of the weaknesses identified are students is not efficient in identifying important contents and it is hard for them to restate important contents using their own words. To them, abridging essays is only with taking the words of the writer that is assumed to be important based on the number of words that is determined by the question.

The misconception of students towards students abridging essays is an effort to abridge the number of words only. There are then students that copy the original sentences from the original text and only leave sentences that is assumed to be less important. Far from that, there are students that is not able to detect the contents or important information. They take the sentences that are less important and do not meet the need of the task of abridging essays. Whereas according to Abd. (2000), the skill of abridging is able to train students with various skills at once as according to the meaning of the following passage:

In schools, the skill is needed by students when they read and want to take notes from materials that was read such as important chapters in text books, and other reference materials such as reference books, encyclopedia, journals, magazines, reports or articles. Other than that, it is not less important the significance of skills of abridging and recording materials that are heard from teachers when they are teaching. Verily the skill of abridging materials that are read (or heard) is significantly useful for students in school, and also to students in college or universities (Abd, 2000).

The essence of abridging essay skill actually is to avoid wrong interpretation and misunderstanding from happening. If this happens, it is highly possible that facts can change, meaning can become distorted, and positive stories can become negative.

\section{Purpose of Study}

This study summarizes the strategies of two excellent students in the process of abridging essays in the classroom. Description of the forms of action in process of abridging essays of these two excellent students can be used as a guideline to increase the skill of abridging essays of students in secondary school level. This study seeks to investigate the steps of abridging essays practiced by excellent students. 


\section{Objective of Study}

This study consists of the following objectives:

- Display the skill of students interacting with material or text that is given by the teacher;

- Analyzing student perception in the process of abridging essays.

\section{Question of Study}

Through this study, a few study questions or query is sought of its answer. Through this study, the cause of the problem can be detected and solution of problem can be proposed. This study tries to answer two questions:

- How is the process of abridging essay of the excellent student?

- How do excellent students benefit certain skills that is needed when abridging essays?

\section{Importance of Study}

The outcome of study can depict the practice of excellent students in abridging essays especially the ability of recognizing information (important contents) and rewriting of information with limited amount of words. The results of this study can be used to determine teacher innovation and the side that is related to teach abridgement of essays in a more effective way. Students are also expected to be able to change the misconception that tasks of abridging essays are not just abridgement of the amount of words.

\section{Limitation of Study}

This study is done using qualitative methods and due to that, the sample that is used is relatively small, that is 2 student of secondary school two at one of the secondary in the Brunei District and Muara, Negara Brunei Darussalam. The outcome of the study does not conclude the situation of the essay abridgement skill ability level of the students in the secondary grade in Brunei as a whole.

\section{Definition and Concept of Abridging Essays}

According to Zainal (2002) abridging essays is cutting and shorting a talk to take only its content or meaning. Based on this definition abridging essay is an effort to shorten essays with taking the important contents only.

While Ong (1992) has the opinion that intrinsically, abridgement is a congnitive process or thinking that involves reparaphrasing process of the abridgement that also has processes of labelling and meaning. It is a cognitive process because solving of a particular abridgement essay need thinking. In this definition, emphasis is made towards the role of skillful thinking when abridging essays. Work of abridging essays is produced after the occurence of cognitive process, that is understanding through process of labelling and meaning dan rewriting through paraphrasing processes.

This is also admitted by Abd (2000), where he stated that at the base of it, the process of abridging essays have the purpose of testing and involves two types of language skills that are reading and understanding a piece of reading skill, and skill of writing based on a piece of reading. Both of these skills are skills that are needed along the process of abridging essays. Nevertheless, in certain stages, certain skills will be used more than others, as an example, 
in the early stages of abridging essays, reading skills are used more than writing skills. However, these language skills is needed to be used to complete the task of abridging essays. This is as the following statement:

One is just to shorten only, that is to give content of an essay that is extended with little words, removed are a number of needed from its decoration and sayings that are repeated and take from its meaning that are big only. Another thing is to shorten it until the finality of abridgement that can be gained, that is to take the thick or core only and is thrown of its skin, stem, leaf, and flowers (Zainal, 2002).

Both of these forms of abridgement needs to be implemented when abridging essays. According to Abd. (2000), the practice of abridging is a language skilll that practical and useful. On this basis, students must be thought and trained as fast as possible at the early stages of secondary school.

As a whole, abridging essays are a practice to interact with consiced texts with application of language skills. It also is related to preparing the student to master the skills of finding, gathering and manipulating information. The following parts explains abridging essays as a practice that intertwines language skills.

\section{Abridging from the Perspective of Language Skill}

Teaching and learning of language skills, that is reading and comprehensive skills, writing skills, listening and speaking skills must be thought integratively. This is because these skills are in need of one another. All these skills are related even if seen from the usage side in learning they are complementary. This is clear admittavely as in the following passage:

Teaching and learning of language literacy in classrooms must happen integratively. The members of language education believes that every language skill must be taught and learned together. Teaching of literacy skill that is divided is less able to encourage growth of high communication skill between students, in the form of oral nor writing

(Roselan, 2003:1).

Based on the above opinion, teaching of language skills that is seperated can not encourage growth of communication skills that is desired. Therefore, it is decided that teaching and learning of langauge skills must be done integratively. According to (Roselan, 2003:1), teaching of language skills that does not involve activitiy of integrated language skills that is available contributes to weakness of students pperformance in writing of the Malay language. This is because writing is a highly skillful language. However writing needs aid from the efficiency of hearing, oral interaction, reading and thinking to exist firmly and steadily.

In connection to that, practice of abridging essays is evidently a practice that is ideal, that can fulfill the needs of integrative language skills. When abridging, students can read, understand while rewriting information that was obtained in the form of a summary. This is appropriate with the opinion of Kamaruddin \& Siti (1997) which states that practice that needs student to rewrite a part of the text that is important and abridging is encouraged. According to them agian, the subject of teaching and writing that is taught in schools are not seperated by its nature. In fact it must happen simultaneously or concurrently. Focus towards the union of reading and writing skills can produce language skills that are more effective. 
The use of writing materials for teaching and learning of writing must be practiced. Before the activitty of writing starts, other activities can be done. According to Kamaruddin \& Siti (1997), teachers must obtain writing materials that can be used as discussion or practice material that is related to begin writing. This means the practice of abridging essays is very appropriate with their opinion. It is once again stated, that in abridging essays, before students abridge (rewrite) they have to first read the passage, understand the passage or do activiites such as discussing with friends or the teacher.

\section{The Relationship of Essay Abridgement with Writing Skill}

Abd. (2000) states that basically the process of abridging is purposed to test and involves two kinds of language skills, which are skill of reading and understanding a piece of reading material, and writing skill based on a piece of reading material. This means the relationship between reading and abridging essays exists. Clearly, the text that is intended to be abridged must first be read and understood by students or readers.

When abridging essays, students read consiced texts to seek available information, after detecting those information, that information will be taken out to be used again and write the abridgement using their own words. During the reading, students communicate with the mentioned writer of the text. This is expained by Smith \& Johnson (1980) in Marohaini (1999) which states that the process of reading establishes communication. The process of reading is actually a communication process because in the action of reading occurs exchanging ideas between the writer and the reader.

When reading also students will interact with abridged materials. This interaction encourages thinking, feeling, and imagining activities of the reading. This is all to understand the contents, information, explanation, or things that wants to be delivered by the author. Therefore, the action of reading is a process of interaction between the student (reader) and text author (Marohaini, 1999). Marohaini (1999) also emhpasizes that in the process of reading, the aspect of pronunciation is less being made important. In the process of reading, the main objective is to understand the reading through the processes of thinking, feeling and imagining what is read. This is very appropriate with the practice of abridging essays. At the stage of preabridgement, students will do a silent reading in order to understand the meaning of the passage and gather information that is available before going to the stage of abridgement that is dominated by the activitiy of writing. So, it is clear that the reading in context is purposed to find the general information, and in the context of abridging essays specifically, the aspect of pronunciation is less made important.

\section{The Relationship between Abridging Essays with Writing Skills}

In the era of prioritizing the ability of gathering information, every individual needs writing ability of the best caliber. This is because according to Roselan (2003), with writing ability, an individual can store information that is increasing, from time to time. This is also mentioned by Flower (1989) in Roselan (2003) that it is as tough writing becomes a system of artificial storage for humans.

Apart from storage for information, writing is also part of the communication system that overcomes the border of space and time (Roselan, 2003). The importance of writing is not 
limited, whether it be in formal events or daily activities that are not formal. The writing activity still colours our lives, as in the following statement:

In fact in our daily life even we can not disregard the significance of writing. At the very least we have to write a small note to state a matter to relatives, teachers, and friends, such as leaving a message, or tell parents that we are going to house of a friend, tell a roomate that we are going out for a while and its like. (Roselan, 2003:vii)

If compared to the above statement with the activity of writing while abridging essays, all of it is accurate. In abridging essays, after reading and understanding the passage, and after gathering and picking out important contents, the student will start to write for the purpose of delivering ideas, arguments and materials agian that is available in the form of writing that is consice, clear and effective, that is said as abridgement.

According to Kamaruddin \& Siti (1997), every writing activity happens in a situation, that involves interaction between the writer, subject and its reader. This does happen in the practice of abridging essays. The teacher chooses an abridged text (so we can assume the teacher as the writer, because of the want to try the student if he or she can accept the message or not) and ask the student (reader) to read and understand the abridged text (subject). In fact, the interaction of the writer -subject - reader in abridging texts happens in the form of two ways. This is because after the student becomes the reader (understanding the abridged text), students will write (writer) again anything that was understood (subject) in the form of abridgement, while sending it to the teacher (reader) to be evaluated. This is prevalent in showing the appropriateness of essay abridgement practice to generate writing skills. The role of teachers as readers happen when evaluating the writing of the student.

Essay abridgement practices also has the purpose so students are exposed to the forms of writing, writing sections that are related to the component and putting important contents, supporting contents, description, examples and others. All the practices that is there in abridging essays contributes to the need of writing subject such as mentioned in the above.

Next, understanding reading, arranging and recording contents systematically and producing forms of writing that are abridged that is mentioned in the third paragraph above also is a part of the activities in the practice of abridging essays. Based on this comparison, the practice of abridging essays is closely related to the need of writing. This means that the practice of abridging essays is very important to be mastered by students because all the activities that are done will encourage mastering writing skills.

\section{The Relationship of Abridging Essay Skills with Thinking Skills}

In truth, the overall activity and stage in abridging essays involves activities and skills of thinking. Students must first read silently for the purpose of understanding the passage that is given by the teacher. The produce of this understanding will be used at the next abridgement process. The meaning and understanding concept that is used at the time of abridging the essay is the same as the understanding that is always mentioned as thinking skill. According to Marohaini (1999), understanding is the ability to establish, interpret, and value something related to the matter or anything that is read. Understanding is a process to achieve meaning from communication by way of oral, writing, or usage of certain symbols. 
This process also covers mental processes that are complex such as spotting words, choosing the appropriate meaning, establishing generalization and also evaluating. Understanding is a completion that is important to the action of reading. Without understanding of anything that is read, a reading action is not complete and can not be recognized as an act of reading. In short, it can be said that reading is understanding.

It is clear that understanding is a process to achieve meaning through of one of the communication medium, that is writing. In this case, abridging essays are a practice so students are able to understand meaning that is contained in the text or passage. The process of understanding inside essay abridgement also involves complex mental processes such as mentioned above. Therefore, without understanding anything that is read, an act of reading is not complete and can not be identified as an of reading. Relatively, the activity of essay abridgement can not be complete if students do not understand anything that is read. This is because essay abridgement practice does not only want to see or test the skill of writing but also test the skill of reading. Verily 'reading is understanding'.

\section{Previous Studies}

There is a study by Rohaida (1999) that studied about the mistakes done by students when summarizing esssays. It has to be explained that summarizing essay is different from abridging essay in the context of Brunei.

In addition, there is a study about adridging essays by Rozaiman (2007). The study found that students are weak by doing various faults in abridging essays that are related to the skills of reading, understand, writing and grammar. His study proposes that the method of essay abridgement teaching has to touch on the type of fault that is done by the student.

Although abridging essays are not well studied and overlooked by the observation of language researchers, this does not mean that the component of the essay abridgement in the Malay Language subject is not important. The skill of abridging essays is a practice that is concise and is able to test the mastery of the student towards language skills. Although the stage or grade of essay abridgement is divided into three stages, that are pre-abridgement, abridgement and post-abridgment, there is a high possibility that the outcome of the study will obtain something that is different, especially from the aspect of steps of abridgement for every stage or grade. The outcome of the study may show the stage or grade that is more holistic, more practice and appropriate with the needs and skill of the studied student. This means anything that is discussed in the literature study is not only a guide that is compulsory to be followed. All of it is just a research guide and this guide must not control the outcome of the study. Due to the study about essay abridgement is limited, so this study is hoped to expose the steps, processes, activities and skills that can be used and accessed by the students.

\section{Framework of Study}

Appropriate to the purpose of this study, that is to investigate the process of essay abridgement in classrooms and the behavior of two students while the process of essay abridgement is happening, therefore the qualitative method is chosen. This selection is appropriate because this study focuses on the process of the phenomena that is studied. 


\section{Place of Study}

In qualitative study, the reliability and trustworthiness of the study outcome more or less is influenced by the place of study. This is because qualitative study tends to determine that thr phenomena that is studied must take place in a place that is ready and not made up. Appropriately, this study is done at the place where the process of teaching and learning of essay abridgement happens, that is in a classroom at a secondary school in the district of Brunei and Muara, Brunei Darussalam. This school is near to the resident of the researcher. This is important to reduce the obstructions to the researcher to come to the place of study. The researcher must be at the research place at the time that is determined, for instance the timetable of learning.

\section{Participant of Study}

For the need of this study, the researcher has chosen two excellent students in year 8 as the participant of study. This selection is not made purposed randomly (purposive non-random). To adapt to the principal of study, that is participant of study as the expert in the phenomena that is to be studied, then the researcher has chosen the students from the best class, that is from year 8A. These two students always get results that are excellent in the Malay Language subject, including component of abridging essays. The selection happens through teacher nomination and based on achievement records

\section{Method of Data Gathering and Collection}

Appropriate to qualitative study, this study chooses three instruments of study to collect and gather data, that is from observing, interviewing and document analysis.

Observation is done when teaching and learning of abridging essays is conducted as a whole. However, due to the purpose of study, observation will be focused to the interaction of both the sample students during the process of essay abridgement.

Interviews are carried out after doing observation. Interviews are done for the purpose of completing the data that is obtained during observation. In addition, interviews are for the purpose to establish triangular data. Apart from interviewing study samples (Dk. Nurul \& Amirul lq), researchers also interviewed $\mathrm{Cg}$. Dewi (participant of study) to get validation and trustworthiness of data by comparing and analyzing data when the study is being implemented. Interview is recorded using a recording device and transcribed.

To strengthen the obtained data, the researcher also analyzed the supporting documents. Among the documents are achievement records of sampled researched students in abridging essays, practice books of abridging essays, abridgement essay draft papers and teaching preparation for the teachers involved (Cg. Dewi)

\section{Method of Data Analyses}

Data analyses is done at two stages. First, is analysis of data during data collection. At the time of data collection, analyses is done towards the data obtained. Therefore, after the observation is done, Site Research Observation Note will be reviewed and rewritten completely at the Complete Research Observation Note. After that it will be abridged to the Abridged Research Observation Note. The same matter is used to interviews that will be transcribed to become Site Interview Note while is abridged to become Abridged Research 
Interview Note. Supporting documents will also be abridged. After all is abridged, the next process is to analyze that will be noted using Memo Research Note. All of this is done so the data that is succesfully gathered can be goverened well and not forgetton.

Secondly, is analyses after data collection. At this stage, the researcher will make data filtration that is needed for the purpose of study. The data that was gathered will be presented, analyzed, until there is a conclusion. For verification and trustworthiness, the method of triangulization of data is used apart from validation of study participants.

\section{Research Findings}

This research finding is divided in three big parts, that is research findings at the stage of preabridgement, research findings at the abridgement stage and research findings at the postabridgement stage. This division is made based on the strategy stage of essay abridgement that is practiced by two excellent research participant students. The presentation of this study is made to compare the strategy of both of the research student sample.

\section{Pre-Abridgement Stage}

The pre-abridgement staage is the first stage in the process of abridging essays. In this stage, students make preparations or arrangements before abridging essays or questions that is given by their teachers. Language skills that dominate in this stage is the reading skill. Despite that, the strategy of making preparation is different between Dk. Nurul and Amirul Iq. The following explains the preparation and strategies of both of the students.

\section{Preabridgement Stage of Dk. Nurul}

In this stage, Dk. Nurul (alias) reads the abridged text 3 times consequtively in silent. To understand the abridged text that is given the teacher, Dk. Nurul tries to correlate the information in the text with the existing knowledge. Information about the drug that is expressed in the summarized text will be correlated with the existing knowledge such as the drug information and current issues that was reported through news programs, televisyen programs, and advise from parents.

During reading, Dk. Nurul will start marking the signifcant contents. Dk. Nurul chooses contents that are important based meaning that is contained in a sentence. If the meaning of the sentence brings meaning that is assumed to fulfill the theme or questions of the abridged text title; therefore, the sentence will also be marked and assumed as important contents. Apart from marking the important contents, Dk. Nurul also marks the words and sentences that are not needed. These sentences will then be left, only sentences that are considered important will be taken out and inserted into the abridgement draft.

After settling the important contents, Dk. Nurul starts to take the contents out into the 'summary paper' (paper draft). These contents will then be organized and made 'notes' or 'non-original abridgement' (abridgement draft). The list of important contents is taken out and organized at the 'summary paper' based on the original paragraph organization while marked at the side with P1 until P5. P1 means 'content from paragraph 1', P2 means 'content from paragraph 2 ' and so on until paragraph 5 . Apart from that, Dk. Nurul also uses the numbers 1 to 5 to organize important contents. This means if the content is taken from paragraph 2 , it is not necessary that the content is written back in the abridgement as the 
second sentence. For example, Dk. Nurul takes two important contents from paragraph 1 and two important points from paragraph 2. After Dk. Nurul rearranges these contents, two contents that were taken from paragraph 2 becomes the third and fourth sentence in the abridgement.

While forming the sentences in the 'paper summary', Dk. Nirul has started counting the total number of words that has been used. This is done to control the number of words that are used so it does not exceed the limit.

\section{Preabridgement Stage of Amirul}

Amirul (alias) starts working on abridging bt reading the text silently. If Dk. Nurul reads for 3 times, Amirul reads once and right away finds the important points. Once getting the important 'points', Amirul will straight away 'shortens' (abridges) the sentences with 'new sentences' (own sentences) and put them into the 'trial paper' (draft paper 1 )

When putting the important 'points' in the the 'trial paper', Amirul will right away calculate the number of words as soon as finishing forming two pieces of sentences. This is done so that the number of words that are used are enough and not wasted. Additionally, Amirul also edits the sentences that he made so it becomes easy to be understoon by the reader (teacher).

\section{Abridgement Stage}

The abridgment stage is the second stage in the process of abridging essays. In this stage, students will revise the finished abridgement. Revising or editing may happen from the part of the preparedness or readinesss of the important contents in the pre-abdridgement stage. The language skill that dominates this stage is the writing skills. Nevertheless, the strategy that is used by both student of this spample when carrying out the following task in this abridgement task seems to be different. The following explains strategies of both studen in the abridgement stage.

\section{Abridgement Stage of Dk. Nurul}

In the abridgement stage, Dk. Nurul directly takes the abridgement book and starts making real or complete abridgment. Important notes in the form of sentences start to be rewritten in a paragraph. At this stage, the original abridged text is no longer needed. The real abridgement is written fully based on the contents that is noted in her 'summary paper'.

\section{Abridgement Stage of Amirul}

If Dk. Nurul made real abridgement in the abridgement book. Different is the strategy of Amirul. In this stage, Amirul uses paper draft 2 that he calls 'preparation paper'. In this 'preparation paper' Amirul tries to make real abridgement. This abridgement is not in the form of draft but a complete abridgement that is supposed too be done in a abridgement book. As a real or complete abridgement, Amirul uses only a paragraph as required by the guide for essay abridgement. Abridgement at the 'preparation paper' is made based on important 'points' that are prepared by the 'test paper'. At the time of writing this real abridgement, change only happens from the side of sentence arrange and number of words used. After all is done, only then Amirul rewrites the real abridgement in the abridgement book. 


\section{Post-Abridgement Stage}

The post-abridgement stage is the last stage in the process of essay abridgement. In this stage, students will revise the abridgement that is completed. Students will recheck the abridgement that is completed. Revision or editing may happen from the aspect of number of words, choose of words, organization of sentences, grammar, even reducing or adding abridgement content. After finishing the abridgement editing, students will copy the abridgment into the abridgement book. This means that the abridgement is free from errors of typing, grammar, number of words that is relevant as the limit and others. The language skill that dominates stage is the skills of editing and grammar knowledge. Nevertheless, the strategy that is used in the post-abridgement stage seems to be different. The following explains the strategies of both students in the post-abridgement stage.

\section{Abridgement Stage of Dk. Nurul}

In this stage, Dk. Nurul has not produced an abridgement that is complete and clean. In fact the real abridgement still contains errors has been copied to the abridgement book. Dk. Nurul still makes the editing in the abridgement book. Dk. Nurul eliminates or reduces the abridgement contec due to having exceeded the number of words. In this stage, Dk. Nurul still refers to the significant content at her 'abridgement paper'. Dk. Nurul uses the ' $X$ ' mark to mark the contents that could not be included in the abridgement in the abridgement book. Dk. Nurul also uses the '?' mark to mark contents that are hard to be inserted in the real abridgement due to number of words that are limited. In this stage also, Dk. Nurul edits the number of words, grammar and calculates the number of words as a whole.

\section{Abridgement Stage of Dk. Nurul}

In this stage, Amirul copies back the real abridgement that has been completed in the 'preparation stage'. However, although done, Amirul still makes edits from spelling and writing, length of sentence and organization of sentence. In this stage activities of calculating the number of words still happens.

Based on this study finding, both of the study sampel uses the strategies that are quite different. Eventhough that is the case, the stages of abridging essays still goes through both of them.

\section{Discussion}

In the post abridgement stage, excellent students does the reading in silence. They try to interract with the writer through the process of understanding the information that with the writer through the process of understanding information that wants to be delivered by the writer. This is done to understand the content, information, explanation or things that want to be delivered by the writer. Through this action of reading, the process of interaction between students (reader) and the text writer occurs (Marohaini, 1999). The next interaction encourages thinking, feeling and imagining activities of anything that is read. So, the action of Dk. Nurul reading the abridged text for 3 times consequtively can we understand as the effort to understand the information that wants to be delivered by the writer of the abridged text.

Both of the samples also reads the abridged text in silence. According to Marohaini (1999) in the reading process there is the purpose of understanding information, while the aspect of pronunciation is less made important. In the process of reading, the main purpose is to understand information throuth the process of thinking, feeling and imagining the general 
information, and in the context abridging the text especially, the aspect of pronunciation is less emphasized.

To understand the abridged text that is given by her teacher, Dk. Nurul tries to correlate the information about drigs that is highlighted in the abridged text with the drug information and current issue in that was reported through news programs, televsiyen programs, and advise of parents. Waht is done by Dk. Nurul is actually a process that establishes meaning through the process of correlation of correlating infomration with the available knowledge. This is as explained by Marohaini (1999), which states that understanding is the ability to establish, interpret, and evaluating something that is related with a matter or anything that is read. Understanding is either process to achieve meaning from communication from oral, reading, or usage of certain symbols. This process also governs the complex mental processes such as identifying words, choosing appropriate meaning, correlating ideas with knowledge and experience that is available, organizing ideas, establishing generalization and also evaluating.

After understanding the information that is delivered by the writer, both of the students start to find for important contents. Dk. Nurul uses the strategy of marking contents on the abridgement paper while Amirul does not. Amirul straight away puts out the important contents and lists them in the 'preparation paper' (draft 1). Although their strategies differ, the need to find important contents happens for both of them. This is indeed worthy because abridgement is a re-deliverance of important content using own words. According to Zainal (2002) abridging essays is cutting and shorting a speech to take only its content or meaning. Based on this definition, essay abridgement is an effort to shorten essays by taking only the important contents.

The draft paper usage happens to both of the study sample. For Dk. Nurul the draft paper is said as 'summary paper'. While for Amirul, the draft paper consists of two types that are 'test paper' (draft 1) and 'preparation paper' (draft 2 as real abridgement). This use of draft paper is significant when abridging essays. It is in this paper students list important contents, rearrange it and as preparation to write the real abridgement. These skills must be mastered by students to become a talented writer. Essay abridgement is actually a practice of gathering information and this skill needs students to understand reading material to be able to organize and record as reference (Kamaruddin \& Siti, 1997).

Through essay abridgement, students will learn ways to gather information through reading, thinking, understanding, marking important contents, taking out important contents and others. In relation, the practice of abridging essays have the potential to provide space for teaching and learning integratively. This can be explained simply. The practice of abridging essays needs application of language skills while going through the process of abridging essays that is divided into pre-abridgement, abridgement and post-abridgement. More than that, the practice of abridging essays also encourages teaching and learning of language skill that is combined with the thinking skill. The matter is as the following statement:

If the teaching implementation of skill literacy is done in a balanced way, through integration skills of hearing, speaking, reading and writing (Silliman \& Wilkinson, 1994). As a consequence, the high literacy formation and development of students becomes more 
secured. Besides, thinking skills is needed to be integrated with those literacy skills (Bareiter \& Scadarmalia, 1987; Calfee \& Nelson-Barber, 1991; Block, 1993 in Roselan, 2003:1).

When forming sentences in the draft paper, Dk. Nurul has started counting the number of words that was used. The same is done by Amirul. When inserting important 'points' in 'test paper', Amirul will immediately count the number of words right after finishing forming two sentences. Counting the number of words that is used is very important in abridging essays. Students must be able to use the number of words that is economical and does not exceed the determined amount.

Next in the abridgement stage, excellent students will start writing the real abridgement outcome. Important contents are elaborarated using full sentences, correct grammar and importantly of their own words. However, the meaning of the own words does not mean using words that are one hundred percent different. Students are not allowed to recopy the words of the write withought even a slight of change. Change in the sentence structure is indeed enough. Both of these study sample succesfully executed this task. However, there are differences from the strategy that is used by both of the students.

Dk. Nurul does the abridgement straight into the abridgement book while Amirul writes the abridgement in a blank paper and is called 'preparation paper' They no longer use abridgement texts. In realation, the abridgement is formed based on the important contents that is prepared in the 'summary paper' for Dk. Nurul and 'test paper' for Amirul. They also have succeeded in following the guide to essay abridgement, that is by making the abridgement in only a paragraph. According to Abd. (2000), abridgement is produced in a paragraph only. The number of the original paragraph is not maintained due to the element of paragraphing that is made unavailable while important contents is untitled in an essay paragraph.

Based on the guide that was by made by Abd. (2000), in the post-abridgement stage, there are two things that has to be done consequtively. First, students must make revision so that there is not sentences that are less grammatic, errors in spelling and mistakes in punctuation marks. Secondly, after being satisfied with the with the abridgement draft that was written and fixed, only then it is copied to the abridgement book in the clean form. This study finds that both of the study samples did not do the things that is in the essay abridgement guide above. Although the editing is ran by both of the samples in this stage, however when they copied the last abridgement version into the abridgement book, they still do editing. Finally, the final abridgement in the abridgement book succeeded to be displayed neatly although there was snippets of editing in the last second until visually the abridgement looked a little untidy.

\section{Summary of Excellent Student Essay Abridgement Strategy}

Actually, until now the strategy of essay abridgment has not been determined as a definite by researchers of the language education field.

Abd. (2000); Zainal (2002); and Ong (1992) stated that the matters that are always only talked about are the steps or processes of abridging essays. This study succeeded in summarizing the strategy of abridging essays into three stages that are pre-abridgement, abridgement and post-abridgement. The essay abridgement strategy stage division is made based on the stage of the essay writing is also divided into pre-writing, draft writing and revision and editing (Applebee, 1981; Peacock, 1986; Meyer, 1989; in Juriah \& Dayangku, 1998). 


\section{Essay Abridgement Strategy}

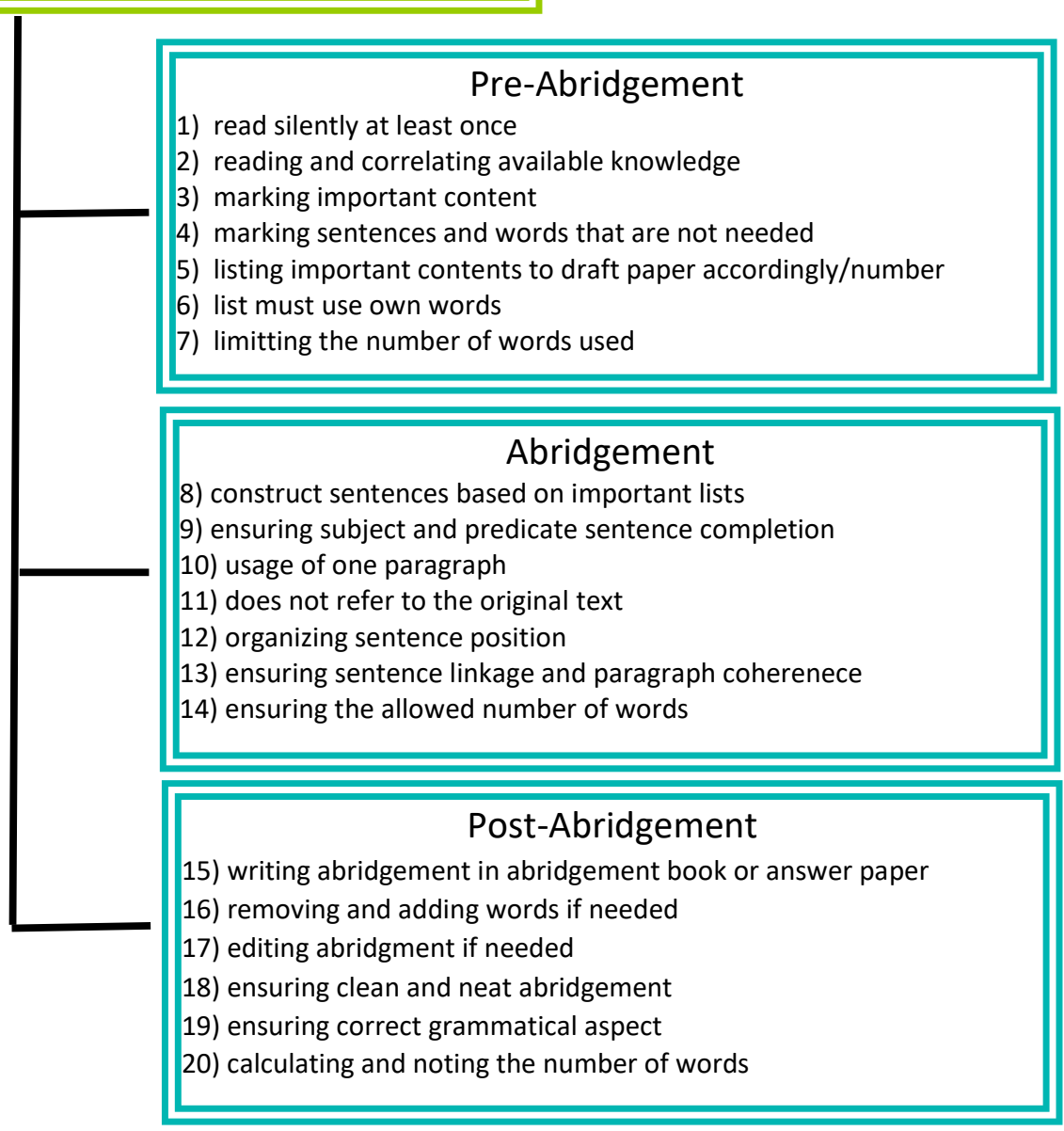

Figure 1: Excellent Student Essay Abridgement Strategy Stages

Although this division is made based on three stage of writing skill, however, the steps that are in the pre-abridgement, abridgement and post-abridgement are not based on the level of the writer. Based on the comparison made there is a significant difference between the levels of of essay writing with levels of essay abridgement. For division of these abridgement levels, the researcher reuses the strategy that is practiced by excellent students.

\section{Implication of Study}

The findings of the study depicts the practice of excellent student in abridging essays through three stages that are very effective. The stages can be used as guidance steps that are effective in learning abridging essays. Every stage also displays various ways to overcome the weakness of students in the skill of abridging essays. The findings of this study is hoped to contribute to additional information in this study field. The study of essay abridging through qualitative approach has not been done, especially in Brunei Darussalam. The findings of the study and discussion with literature summary is able to give information and views that can be used by Malay Language teachers in fixing teaching and learning of abridging essays. The findings will also be giving imprints in preparing practicing teachers and can be used as a measurement to develop syllabus with preparation of teaching material. 


\section{Conclusion}

Although there are differences in the way of the strategies of essay abridgement, nevertheless both samples has gone through the same abridgement process, that is divided into three stages or levels, that are pre-abridgement stage, abridgement stage and postabridgement stage. These stages of essay abrigement have not been expressed by the language researchers. Based on these findings, the process of abridgement happens according to the sequence that is present in the mentioned stages. This means students must undergo every of those stages. Students cannot leave the pre-abridgement stage.

In the pre-abridgement stage student will use the reading and thinking skill. Without the occurence of this reading and thinking processes, students will not be able to step into the abridgement stage. This is because abridgement will only be able to be done after students understand the information that is present in the abridgement text. To understand it, the process of reading and understanding (thinking) is needed.

In the abridgement stage, writing skills dominates more in the activity of abridgement. While in the post-abridgement stage, skill of writing and editing (grammar skills) dominates more. It can be concluded that in abridging essays, skills such as reading and understanding skills, thinking skills, gathering information skills, writing skills, editing skills and grammar skills has been utilized by the sample research students.

\section{Theoretical and Contextual Contribution of This Research}

This study summarizes the strategies of two excellent students in the process of abridging essays in the classroom. Description of the forms of action in process of abridging essays of these two excellent students can be used as a guideline to increase the skill of abridging essays of students in secondary school level. This research finding is divided in three big parts, that is research findings at the stage of pre-abridgement, research findings at the abridgement stage and research findings at the post-abridgement stage. This division is made based on the strategy stage of essay abridgement that is practiced by two excellent research participant students. The presentation of this study is made to compare the strategy of both of the research student sample.

\section{References}

Abdul, S. S., Nuraini, Y., \& Mohd, I. A. (2003). Bahasa Melayu Komunikasi. Pahang Darul Makmur: PTS Publications \& Distributors Sdn. Bhd.

Abd, A. A. T. (2000). Pedagogi Bahasa Melayu. Kuala Lumpur: Publications \& Distributors Sdn. Bhd.

Block, C. C. (1993). Teaching the Language Arts: Expanding Thinking Though Student-Centered Instruction. Boston: Allyn and Bacon.

Breiter, C., \& Scardamalia, M. (1987). An Attainable Version of High Literacy: Approaches to Teaching Higher-Order Skills in Reading and Writing. Curriculum Inquiry, 17(1) : 930.

Calfee, R., \& Nelson-Barber, S. (1991). Diversity and Constancy in Human Thinking : Critical Literacy as Emplifier of Intellect and Experience. In Hiebert, E.H. (Ed.). Literacy Foradiverse Society : Perspectives, Practices, and Policies. New York : Teachers College Press. 
Juriah, L., \& Dayangku, J. P. D. (1998). Pengajaran Menulis Melalui Pendekatan Proses. In Juriah, L. (Ed.). Inovasi dalam Perkaedahan Pengajaran Bahasa, Sains Sosial dan Teknologi Maklumat (pp. 37-53). Bangi: Universiti Kebangsaan Malaysia.

Kamaruddin, H. H., \& Siti, H. H. A. A. (1997). Penguasaan Kemahiran Menulis. Selangor : Kumpulan Budiman Sdn. Bhd.

Marohaini, Y. (1999). Bacaan dan Kefahaman, Kuala Lumpur: Dewan Bahasa dan Pustaka.

Ong, C. G. (1992). Kaedah Meringkaskan Karangan. Kuala Lumpur: Arenabuku Sdn. Bhd.

Rohaida, H. (1999). Analisis Kesilapan dalam Merumuskan Karangan: Satu Kajian Kes. [Master's Degree Dissertation].

Roselan, B. (2003). Kaedah Pengajaran dan Pembelajaran Penulisan Bahasa Melayu. Selangor: Karisma Publications Sdn. Bhd.

Rozaiman Makmun. (2007). Analisis Prestasi Kemahiran Meringkaskan Karangan Pelajar Peringkat Menengah di Brunei Darussalam. [Master's Degree Dissertation].

Rozaiman, M. (2009). Meringkaskan Karangan: Konsep, Panduan, Teknik, dan Penilaian. Bandar Seri Begawan: Dewan Bahasa dan Pustaka.

Silliman, E. R., \& Wilkinson, L. C. (1994). Discourse Scaffolds for Classroom Intervention. In Wallach, G.P. \& Butler, K.G. (Ed.). Language Learning Disabilities in School-age Children and Adolescents. New York: Macmillan College Publishing Company.

Zainal, A. A. (2002). Ilmu Mengarang Melayu. Kuala Lumpur: Dewan Bahasa dan Pustaka. 